УДК 373.3/.5.014.3(477):159.955.5

https://doi.org/10.52058/2708-7530-2021-9(15)-371-383

Неділя Тетяна Вікторівна здобувач вищої освіти, студент магістратури, Національний університет «Чернігівський колегіум» імені Т.Г. Шевченка, вул. Гетьмана Полуботка, 53, м.Чернігів, 14013, тел.: (097) 876-07-49, e-mail: tanyanedelya@gmail.com, https://orcid.org/0000-0002-0147-8298

Кміть Олена Володимирівна кандидат педагогічних наук, доцент, доцент кафедри мов і методики їх викладання, Національний університет «Чернігівський колегіум» імені Т.Г. Шевченка, вул. Гетьмана Полуботка, 53, м. Чернігів, 14013, тел.: (093) 500-58-40, e-mail: elenakmit64@ gmail.com, https://orcid.org/0000-00033396-7798

\title{
КРИТИЧНЕ МИСЛЕННЯ ЯК ПРОВІДНА ТЕХНОЛОГІЯ НАВЧАННЯ В НУШ
}

Анотація. Стабільний розвиток будь-якої країни, ії економіки залежить від якості освіти в цій країні. Реформа системи освіти в Україні, яка проходить в останні роки, передбачає зміну форм і методів викладання, впровадження в освітній процес новітніх технологій навчання, які були б цікавими сучасній дитині, підвищували якість знань та мотивували учнів на самостійні відкриття. В Концепції Нової української школи (НУШ) викладено основні засади реформи середньої освіти. Концепцією визначаються компетентності, які формуються під час освітнього процесу в закладі загальної середньої освіти за допомогою таких технологій як: критичне мислення, навчання у грі, навчання у співробітництві, проектна робота.

Однією 3 провідних сучасних технологій навчання, яка застосовується в НУШ, є технологія критичного мислення. За допомогою цієї технології у молодших школярів розвиваються такі компетентності як здатність до комунікації, самонавчання, самостійності суджень та прийняття рішень. Уроки критичного мислення проходять активно у формі ігор, дослідів, експериментів, що дозволяє учням краще зрозуміти та запам'ятати навчальний матеріал, а також збагнути, як використовувати набуті знання у повсякденному житті.

У статті розглядаються теоретичні аспекти формування критичного мислення у молодших школярів, а також особливості застосування різноманітних прийомів на уроках у початковій школі. Описано етапи уроку, побудованого на основі технології критичного мислення, уточнено прийоми для використання на кожному з етапів, а також визначено характеристики особистості, яка критично мислить. Розкрито актуальність та необхідність формування і розвитку навичок критичного мислення учнів початкової школи. Автори наголошують, що 
технологія критичного мислення в освітньому процесі в НУШ сприятиме підвищенню якості знань, допоможе створити ситуацію успіху, зробити уроки цікавими та виховати творчу особистість.

Ключові слова: Нова українська школа (НУШ), технологія розвитку критичного мислення, навички критичного мислення, прийоми, етапи уроку, молодші школярі.

Nedilia Tetiana Victorivna Higher Education Applicant, Graduate Student, T. H. Shevchenko National University «Chernihiv Colehium», Hetman Polubotok St., 53, Chernihiv, 14013, tel.: (097) 876-07-49, e-mail: tanyanedelya@gmail.com, https://orcid.org/0000-0002-0147-8298

Kmit' Olena Volodymyrivna Candidate of Education, Associate Professor, Associate Professor of Languages and Methodology of their Teaching Chair, T. H. Shevchenko National University «Chernihiv Colehium», Hetman Polubotok St., 53, Chernihiv, 14013, tel.: (093) 500-58-40, e-mail: elenakmit64@gmail.com, https://orcid.org/0000-0003-3396-7798

\section{CRITICAL THINKING AS THE LEADING LEARNING TECHNOLOGY IN THE NUS}

Abstract. Any country's stable development, its economy depends upon the quality of education in this state. The education reform, having being held in the country recently, implies the change of teaching forms and methods, implementation into educational process of innovative technologies which might be interesting for contemporary children, improve the level of their knowledge and motivate them to independent discoveries. In the concept of New Ukrainian school the basic foundations of secondary education reforms are presented. The concept defines competences formed at comprehensive secondary schools by means of such technologies as critical thinking, gamification, cooperative learning, project work.

One of the leading educational technologies applied at the lessons at New Ukrainian school is the technology of critical thinking. Young learners acquire such skills as capability for communication, self-education, abilities to make individual judgements and decisions. The lessons of critical thinking are conducted in the forms of games, researches, experiments that allow students to understand and remember the learned material better and besides comprehend how to apply the acquired knowledge in everyday life.

In the article the theoretical aspects of molding of primary school pupils' critical thinking are considered and also the peculiarities of using various methods at the lessons at Primary school are determined. The stages of the lesson built on the basis of critical thinking are described, the methods applied at different stages of a lesson are clarified, the features of an individual thinking critically are defined. The topicality and 
the necessity of primary school pupils' critical thinking skills formation and development are specified. The authors emphasize that critical thinking technology at New Ukrainian school will promote knowledge improving and it will help to create the situation of success, make lessons interesting and bring a creative personality up.

Keywords: New Ukrainian school, critical thinking technology, critical thinking skills, methods, stages of the lesson, primary school pupils.

Постановка проблеми. В Державних стандартах початкової освіти зазначається, що метою початкової освіти $є$ всебічний розвиток дитини, іiі талантів, здібностей, компетентностей та наскрізних умінь відповідно до вікових та індивідуальних психофізіологічних особливостей i потреб, формування цінностей, розвиток самостійності, творчості та допитливості [1].

Ми живемо в період розвитку цифрових технологій i можемо отримати необхідну інформацію на просторах інтернету. Це дає можливість учням збагачувати самостійно власні знання. Але чи достовірною буде отримана інформація? В інформаційному світі з'явилися небачені чудовиська: «спами», «фейки», «фішинги», «тролінги», «пранки». Світ для пересічної людини став нестерпним та нескінченним жахом [2, с. 14]. Діти беруть на віру все прочитане i почуте. Тому необхідно розвивати в учнів навички критичного мислення, навчати школярів аналізувати отриману інформацію, співставляти факти, перевіряти, робити правильні висновки.

Нові освітні стандарти в Україні визначають 10 ключових компетентностей, спільними уміннями для яких є уміння читати і розуміти прочитане; уміння висловлювати думку усно і письмово; критично мислити; творити; здатність співпрацювати у команді; здатність логічно обгрунтовувати позицію; уміння вирішувати проблеми, оцінювати ризики та приймати рішення; застосовувати емоційний інтелект [3, с.10-12]. 3 огляду на це, розвиток критичного мислення у молодших школярів є досить актуальною проблемою сьогодення. В Концепції Нової української школи саме розвиток критичного мислення у дітей є одним 3 наскрізних завдань освітнього процесу.

Аналіз останніх досліджень і публікацій. Дослідженню проблеми розвитку критичного мислення присвячені праці таких науковців, як М. Ліпмана, Ж. Піаже, Д. Халперна, А. Кроуфорда, Дж. Брунера, Д. Дьюї, Л. Виготського та багатьох інших. У працях зарубіжних дослідників навичка критичного мислення розглядається як процес набуття компетентності і iї реалізації з урахуванням системи особистісних i суспільних цінностей. Серед українських вчених вивченням даного феномену займаються О. Пометун, С. Терно, Н. Вукіна, А. Тягло, О. Бєлкіна-Ковальчук, Л. Пироженко, О. Чуба та інші. У працях вітчизняних дослідників питання критичного мислення розглядається в плані впровадження даної технології в освітній процес для його покращення i ефективності. Науковці в своїх працях описують не тільки теоретичні аспекти проблеми, а й, спираючись на власний досвід, дають практичні поради. 
В умовах реформування освіти в Україні впровадження новітніх технологій в навчальний процес для покращення його якості та ефективності $\epsilon$ досить актуальним питанням.

Мета статті - дати визначення поняттю критичне мислення, вивчити теоретичні аспекти технології критичного мислення, розглянути прийоми, які застосовуються на уроках в НУШ.

Виклад основного матеріалу. У жовтні 2020 року Світовим економічним форумом було оприлюднено звіт «Майбутне робочих місць», в якому представлено перелік навичок необхідних для успішної кар'єри у майбутньому. Серед цих навичок незмінним залишається критичне мислення. Також до переліку додано такі навички як активне навчання та навчальні стратегії, вони в свою чергу тісно пов'язані з технологією критичного мислення і $є$ невід'ємними складовими цієї технології. Саме вміння самостійно навчатися, ефективно використовувати набуті знання, гнучкість та готовність до зміни професії гарантують успіх у майбутньому.

В сучасному світі постає питання виховання творчої, всебічно розвиненої особистості, яка здатна орієнтуватися в великій кількості інформації, швидко адаптуватися до стрімких змін реальності, постійно вдосконалюватися i розвиватися, оволодівати новими знаннями та навичками. Для того, щоб допомогти дітям стати успішними та затребуваними на ринку праці в майбутньому, школа повинна давати не тільки готові знання, а й навчати учнів самостійно здобувати ці знання та застосовувати їх у повсякденному житті.

Кваліфікований і затребуваний на ринку праці фахівець повинен бути: комунікабельним, уміти співпрацювати, критично та креативно мислити, самостійно аналізувати ситуацію (людиноцентричні навички); вміти аналізувати дані, знати бодай одну мову програмування і як розробляти комп'ютерні програми, опанувати основи кібербезпеки (цифрові навички); спроможний оперувати бізнес-процесами, управляти проєктами, знається на цифровому дизайні й комунікації даних (бізнес-орієнтовані навички) [4].

Реформа освіти в Україні направлена не тільки на зміну змісту предметів, що вивчаються, а й на зміну підходів до методики викладання, розширення методичних прийомів викладання, активізацію навчальної діяльності учнів на уроках, наближення тем, що вивчаються, до реального життя.

Сучасний світ складний. Дитині недостатньо дати лише знання. Ще важливо навчити користуватися ними. Знання та вміння, взаємопов'язані з ціннісними орієнтирами учня, формують його життєві компетентності, потрібні для успішної самореалізації у житті, навчанні та праці [3, с. 10].

Запровадження нових освітніх технологій особистісно орієнтованого навчання, це передумова для активної пізнавальної діяльності учнів: нестандартна, цікава, творча робота, яка пробуджує у дітей цікавість до знань і сприяє емоційному, духовному та інтелектуальному розвитку учнів. Однією 3 технологій, яка допомагає учню не тільки засвоїти певну кількість знань, але й 
сприяє розвитку його особистісних якостей, є технологія формування критичного мислення.

На сьогодні в наукових джерелах можна знайти різні визначення поняття «критичне мислення».

Канадський професор Ральф Х. Джонсон визначає критичне мислення як «особливий вид розумової діяльності, що дозволяє людині винести раціональне судження щодо запропонованої ій точки зору або моделі поведінки» [5, с. 8].

О. Тягло визначає критичне мислення як сучасний розділ «науки мислити», який породжується усвідомленням непозбутності помилок i хитрощів у теоретичній та практичній діяльності людини, людства. Воно може бути представлене як специфічний різновид рефлексії, що спирається на елементарну логіку і, ймовірно, на відповідні конкретні науки [6, с. 14].

Критичне мислення - це мислення усвідомлене, самостійне, рефлексивне, цілеспрямоване, обгрунтоване, контрольоване та самоорганізоване зазначає С. Терно [7, с. 15].

Автор підручника «Критичне мислення» Конверський визначає дане поняття як «усвідомлене відношення до процесу міркування, яке передбачає вміння будувати доведення, спростування, вміння висувати гіпотези, проводити аналогії, нарешті, знаходити помилки у своїх і чужих міркуваннях» [2, с. 20].

На думку О. Бєлкіної-Ковальчук «критичне мислення - це системне утворення, що є і якісною характеристикою особистості, і процесом мислительної діяльності, і здатністю людини до осмислення навколишніх подій, і одним із чинників розвитку особистості» [8].

Отже, критичне мислення - розумова діяльність, яка є усвідомленою та самостійною і направлена на виявлення істини та генерування нових ідей шляхом збирання інформації, ïi аналізу, співставлення фактів.

С. Терно виділяє наступні характеристики людей 3 критичним мисленням: чесні перед собою; відкидають підтасування; переборюють плутанину; ставлять запитання; роблять свої висновки на очевидних фактах; слідкують за зв'язком між явищами; інтелектуально незалежні [7, с. 9].

Сучасна освітня технологія розвитку критичного мислення розв'язує такі завдання:

- освітньої мотивації: підвищення інтересу до процесу навчання та активного сприйняття навчального матеріалу;

- інформаційної грамотності: розвиток здатності до самостійної аналітичної та оцінювальної роботи з інформацією будь-якої складності;

- культури письма: формування навичок написання текстів різних жанрів;

- соціальної компетентності: формування комунікативних навичок та відповідальності за знання [9].

Поняття «мислення» в українському педагогічному словнику визначається наступним чином - це вища форма відображення дійсності в психіці, ідеальна діяльність, результатом якої є об’єктивна істина [10, с. 200]. 
До операцій мислення відносяться запам'ятовування, розуміння, аналіз, синтез, застосування, оцінювання. Запам'ятовування, розуміння та застосування належать до процесів нижчого порядку. Тоді як аналіз, синтез та оцінювання належать до операцій вищого порядку. У 1956 році американський психолог Бенджамін Блум розробив таксономію навчальних цілей та результатів [11]. Вона складається з шести цілей, які ставляться вчителем на початку уроку перед учнями та перед собою. Згідно до цілей обираються методи та прийоми проведення уроку з метою більш ефективного розвитку та засвоєння навичок критичного мислення.

Навчити дітей мислити критично - означає правильно задати питання, спрямувати увагу в правильному напрямку, навчати робити висновки і знаходити рішення, для того щоб кожна дитина могла розвинути свої творчі можливості, необхідне розумне керівництво з боку вчителя. Необхідно кожен урок в школі перетворити на урок мислення, спілкування, урок-діалог. Загальна мета освіти сьогодні - виховання культури особистості.

Формулювання запитань $\epsilon$ одним із механізмів формування навичок критичного мислення. Можна з упевненістю сказати, що запитання стимулюють критичне мислення [12, с. 16-17].

Є наступні види запитань.

Запитання на знання - це запитання найнижчого рівня, що вимагає механічного згадування інформації. Такі запитання найчастіше передбачають одну правильну відповідь і використовуються для перевірки знань. Вони не стимулюють розвиток навичок критичного мислення, а сприяють тренуванню пам'яті.

Запитання на розуміння ставляться для розкриття смислу, сутності того, що вивчається, виявлення зв'язків між ідеями, фактами, визначеннями або цінностями.

Запитання на застосування вимагають використання вже відомої учням інформації у нових умовах або ситуаціях. Вони дають можливість розв'язувати проблеми, досліджувати їх.

Запитання на аналіз передбачають розкладання інформації на складові, виокремлення частин та аналіз кожної з виділених частин у межах єдиного цілого.

Запитання на синтез пов'язані із творчим розв'язанням проблем на основі оригінального мислення. Запитання на синтез можуть мати безліч найрізноманітніших відповідей.

Запитання на оцінювання ставляться учням для того, щоб вони сформулювали власні судження про добре i погане або про справедливе i несправедливе [12, с. 17].

Уміння ставити запитання формуються за допомогою таких методів технології критичного мислення як: «Ромашка запитань», «Кубування», «Товсті/тонкі запитання», «3-Х-Д», «Інтерв'ю», «6W», «Банк запитань», «Обмін 
проблемами», «Читання в парах/запитання в парах».

Навичка висувати припущення формується та розвивається при застосування методів «Дерево передбачень», «Вірні та невірні висловлювання», «Кошик ідей», «Мозковий штурм», «Читання з зупинками», «Вилучи зайве», «Припущення на основі запропонованих слів», «Займи позицію», «Дерево рішень», «Лінія цінностей», «Обговорення проблеми в загальному колі», «Чи вірите ви, що...».

Такі методи як «Мозковий штурм», «Займи позицію», «Дерево рішень», «Лінія цінностей», «Обговорення проблеми в загальному колі» допомагають розвивати уміння лаконічно висловлювати та аргументувати власну думку.

Уміння критично читати формується методами «Гронування», «Кластер», «Читання в парах/запитання в парах», «Читання 3 маркуванням», «Ромашка Блума», «Кубик Блума» тощо.

Навичка синтезувати інформацію допомагають формувати такі методи як «Сенкан», «Кластер», «Ментальна карта», «Лепбук», «Хмара слів», «Гронування».

Методи «Бортовий журнал», «Тепер я...», «Шкала думок», «Кубик Блума», «Ромашка Блума», «3-Х-Д», «Тонкі/товсті запитання» допомагають здійснити рефлексію [13].

Для того щоб учні могли скористатися своїми можливостями критичних мислителів, важливо, щоб вчитель розвивав у них низку важливих якостей, серед яких Д. Халперн виокремлює:

1. Готовність до планування.

2. Гнучкість. Готовність сприймати ідеї інших, готовність змінити власну точку зору, зробити щось інакше.

3. Наполегливість. Вчителю слід виробляти наполегливість у напруженні розумових сил, тоді учні обов'язково досягнуть значно ліпших результатів навчання.

4. Готовність виправляти свої помилки. Людина, що критично мислить, зробить правильні для себе висновки, скористається помилкою для продовження навчання.

5. Усвідомлення. Уміння спостерігати за собою в процесі розумової діяльності, відслідковувати перебіг міркувань.

6. Пошук компромісних рішень. Важливо, щоб ухвалені рішення могли сприйняти інші люди, інакше ці рішення так i залишаться на рівні висловлювань [7, с. 8].

Критичне мислення розвивається краще та швидше, якщо на уроках діти постійно активно віднаходять інформацію, співставляють здобуті знання 3 власним практичним досвідом. Учні повинні навчитися піддавати сумніву достовірність отриманої інформації, робити висновки, приймати рішення, вивчати причини та наслідки різноманітних явищ.

В технології розвитку критичного мислення синтезовані ідеї та прийоми технологій колективних і групових способів навчання, також співпраці та 
розвивального навчання.

Структура уроку із застосуванням технології критичного мислення складається 3 трьох етапів: виклик, осмислення, рефлексія. Спочатку учнів потрібно налаштувати на навчання і сприйняття нової інформації, згадати, що уже відомо по темі уроку, потім познайомитися з новою інформацією, і на стадії рефлексії закріпити їх, подумавши, для чого потрібні здобуті знання та як їх можна застосувати на практиці.

Прийоми, які використовуються на етапі виклику, дозволяють учням побачити наявну інформацію, виявити протиріччя, незрозумілі моменти, які i визначають напрямки подальшого пошуку інформації. До цих методів належать: кластер, кошик ідей, асоціативний кущ, мозковий штурм, дерево передбачень, робота в парах, правильні і неправильні судження, діаграма Венна, вільне письмо.

Після такого початку уроку вчитель підводить учнів до формулювання запитань, пошуку, осмислення матеріалу, відповідей на попередні запитання, визначення нових запитань і намагання відповісти на них. Ця друга фаза уроку $є$ основним етапом уроку і називається фазою побудови знань. Дана фаза має на меті: порівняти очікування учнів із тим, що вивчається; переглянути очікування та висловити нові; виявити основні моменти; відстежити процеси мислення (перебіг думок учнів); зробити висновки й узагальнення матеріалу; поєднати зміст уроку з особистим досвідом учнів; поставити запитання до вивченого на уроці матеріалу [14, с. 12-13].

На цьому етапі використовуються такі методи як: дискусія, читання 3 маркуванням, «тонкі» і «товсті» запитання, карта поняття, читання в парах, навчаючи вчуся, концептуальна таблиця.

Коли учні зрозуміли ідеї уроку, до того як урок буде закінчено, необхідно переходити до наступної фази. Учитель спонукає учнів відрефлексувати те, про що дізналися, та запитати себе, що це означає для них, як це змінює їхні попередні уявлення, як вони зможуть це використовувати. Ця третя фаза уроку називається фазою консолідації і має на меті: узагальнити основні ідеї; інтерпретувати вивчене; обмінятися думками; виявити особисте ставлення; апробувати ці ідеї; оцінити, як відбувається процес навчання; поставити додаткові запитання [14, с. 12-13].

На етапі рефлексії доцільно використовувати наступні прийоми: сенкан, бортовий журнал, шкала думок, кластер, кубування, займи позицію, «плюс мінус - цікаво».

Деякі прийоми можна застосовувати на різних етапах уроку. Наприклад, метод «знаємо - хочемо дізнатися - дізналися» використовується як на етапі виклику, так і на етапі рефлексії. Для цього учням пропонується скласти таблицю зі стовпчиками. В перший стовпчик «знаємо» записується інформація, яка вже відома по темі, що вивчається. В другий стовпчик «хочемо дізнатися» записуються питання, з приводу яких виникли протиріччя, і незрозумілі моменти. 
В третій стовпчик «дізналися» вноситься інформація, яку учні вивчили під час уроку.

Також методи «тонкі» і «товсті» запитання, кластер, робота в парах можна використовувати на будь-яких етапах уроку.

Технологія розвитку критичного мислення являє собою набір прийомів, застосування яких дозволяе побудувати освітній процес так, щоб забезпечити самостійну та усвідомлену діяльність учнів для досягнення навчальної мети, допомагає задіяти учнів до активного навчання, і тим самим підвищити якість знань.

Під час проведення уроку в НУШ слід застосовувати різні методи та прийоми розвитку критичного мислення, обираючи їх відповідно до поставленої мети та цілей навчання. Також необхідно враховувати вікові особливості учнів.

Опишемо деякі прийоми розвитку критичного мислення.

Кластер - це графічна форма подачі інформації, коли відбувається виділення основних смислових одиниць, які зображуються у вигляді схеми і позначаються всі зв'язки між ними [15].

Завдання прийому $є$ систематизація матеріалу, встановлення причиннонаслідкових зав'язків між основними змістовними категоріями теми. Робота може здійснюватися індивідуально, в групах, учнем біля дошки, по всій темі, або по окремих іiі блоках. Метою прийому є навчання графічній організації матеріалу, що дозволяе візуалізувати думки, які виникають щодо певної теми, у процесі читання тексту, пошуку взаємозв'язків між окремими поняттями, спільного дослідження інформаційного поля теми [12, с. 26].

Даний прийом навчання може застосовувати на будь-якому етапі уроку.

Інший прийом технології критичного мислення, який часто використовується на уроках, «Істинні та хибні висловлювання». В залежності від етапу уроку вчитель формує висловлювання, які потрібно аргументовано довести або спростувати. На етапі осмислення до уже відомих висловлювань пропонуються невідомі факти, достовірність яких учні доводять або спростовують, використовуючи знання, отримані під час уроку.

Велике значення в технології розвитку критичного мислення мають прийоми, які формують уміння працювати з питаннями. В той час як традиційне навчання будується на готових відповідях, які викладаються учням, технологія розвитку критичного мислення орієнтована на питання, як основну рушійну силу мислення учнів. Одним 3 таких методів $€$ «Ромашка Блума». Мета прийому навчити усвідомленому та цілеспрямованому формулюванню запитань різного типу. Метод можна застосовувати на етапі виклику для формулювання учнями запитань, на які вони відповідають, за допомогою підручника або інших джерел інформації. «Ромашка» складається 3 шести пелюсток, на кожній 3 яких записуються запитання різного рівня: прості запитання, уточнюючі запитання на розуміння, практичні запитання на встановлення взаємозв'язків між теорією і практикою, синтезуючі запитання на встановлення причинно-наслідкових 
зв'язків, оцінні запитання, творчі запитання [12,с. 36-37].

Також на уроках доцільно використовувати прийом «сенкан» в якості інструмента для синтезування та систематизації інформації. Складання «сенкану» $\epsilon$ формою своєрідної творчості, яка вимагає від учнів уміння знаходити в інформаційному матеріалі найбільш вагомі елементи, робити висновки та коротко їх формулювати.

Правила складання «сенкану»: перший рядок - одне або декілька слів, зазвичай іменник, займенник, словосполучення, яке відображає тему; другий рядок - два слова, прикметники або дієприкметники, які описують ознаки теми; третій рядок - три слова, дієслова, які відображають дії теми «сенкану»; четвертий рядок - фраза 3 чотирьох слів, яка показує відношення до теми «сенкану»; п'ятий рядок - одне або декілька слів, за допомогою яких висловлюються почуття та асоціації, пов'язані з поняттям. В «сенкані» не повинні використовуватися однокореневі слова та вказівне слово «це».

Вищенаведений прийом $\epsilon$ незамінним для розвитку мовлення молодших школярів, формує вміння лаконічно передавати свої роздуми, сприяє розвитку образного мислення. Виконувати таку вправу можна і на етапі осмислення, i на етапі рефлексії.

Головною особливістю прийомів $є$ те, що вони допускають різні шляхи вирішення питань, креативність у пошуку правильних відповідей, формуючи та розвиваючи оригінальність та гнучкість мислення, підтримують стійку цікавість до вивчення нового на уроках. Кожен прийом має за мету розкрити творчий потенціал учнів.

Висновки. Сьогоднішні учні молодших класів - це майбутні фахівці, які будуть розбудовувати Україну. Технологія критичного мислення допомагає готувати дітей до реалій сьогодення та майбутнього. За допомогою цієї технології підвищується цікавість до навчання; молодші школярі навчаються думати, спілкуватися, слухати та чути інших; підвищується якість навчання.

Наскільки успішною буде особистість в майбутньому, здатною адаптуватися до змін у житті та діяльності, залежить від набутих умінь та навичок у дитинстві.

Для тих, хто володіє належними знаннями i навичками, оцифрування i глобалізація стали захопливими процесами, що дарують свободу. Але для тих, хто не готовий до змін, ці явища означають нестабільне працевлаштування i життя без перспективи [16, с. 19].

Після проведення уроків із застосуванням технології розвитку критичного мислення завжди з'являються нові ідеї. Це є доказом того, що дана технологія не тільки педагогічна технологія з визначеними правилами, принципами та набором прийомів, а й динамічний, розвивальний підхід до навчання, який доцільно і необхідно використовувати на уроках в НУШ.

В процесі розвитку критичного мислення у молодших школярів НУШ розвивається здатність спостерігати, порівнювати, виявляти, формувати власну точку зору та відстоювати іiі за допомогою логічних доводів; розвивається 
цікавість до пізнання нового; розвивається здатність використовувати в практичному повсякденному житті дослідницькі методи.

Застосування технології критичного мислення на уроках в НУШ робить їх цікавими та жвавими. Розвиваються пізнавальні здібності та пізнавальні процеси особистості: різні види пам'яті, мислення, сприйняття, увага. Використання зазначеної технології орієнтоване на розвиток навичок вдумливої роботи 3 інформацією. Учні думають, розмірковують, читають, пишуть, аналізують, обговорюють. Діти навчаються більш уважно, навчаються генерувати власні ідеї, підкріплювати їх фактами, самостійно розмірковувати, i як результат, підвищується якість знань 3 української мови та предметів в цілому. При формуванні критичного мислення у молодших школярів необхідно навчати їх бачити проблему, ставити запитання та знаходити відповіді на них.

Що точно можна стверджувати - нам необхідно постійно вдосконалюватися i ставати кращою версією себе. Необхідно порівнювати себе лише із собою вчорашнім. Саме власна ціль, наші унікальні досвід і вміння роблять нас справді потрібними й бажаними, що в свою чергу призводить до економічного успіху, індивідуального добробуту й соціальної рівноваги [4].

Таким чином, застосування технології розвитку критичного мислення на уроках в НУШ дозволяє створити умови для розвитку творчого потенціалу особистості, розвитку пізнавальних здібностей та комунікативних навичок молодших школярів. Навчати молодших школярів критично мислити - отже, навчати критично слухати та сприймати, осмислювати та аналізувати нову інформацію, творчо застосовувати та доводити свої знання, розвивати та вдосконалювати себе.

\section{Jimepamypa:}

1. Постанова Кабінету міністрів Про затвердження Державного стандарту початкової освіти № 87 від 21 лютого 2018 року. [Електронний ресурс]. Режим доступу: https://zakon.rada.gov.ua/laws/show/87-2018-\%D0\%BF\#Text.

2. Конверський А.Є. Критичне мислення. Підручник для студентів вищих навчальних закладів усіх спеціальностей. Київ: Центр учбової літератури, 2020. 370 с.

3. Нова українська школа. Концептуальні засади реформування середньої школи [Електронний ресурс] 2016. Режим доступу:https://mon.gov.ua/storage/app/media/zagalna\% 20serednya/nova-ukrainska-shkola-compressed.pdf.

4. Миколаївський обласний центр зайнятості. Топ навичок для успіху в 2025 році [Електронний ресурс]. Режим доступу: https://mik.dcz.gov.ua/publikaciya/top-navychok-dlyauspihu-v-2025-roci.

5. Н. В. Вукіна, Н. П. Дементієвська, Критичне мислення: як цього навчати. Харків: «Основа»: «Триада +», 2007. 112 с.

6. Тягло О. В. Критичне мислення. Харків: «Основа»: «Триада +», 2008.192 с.

7. Терно С. О. Методика розвитку критичного мислення школярів у процесі навчання iсторії. Запоріжжя: Запорізький національний університет, 2012. 70 с.

8. Бєлкіна-Ковальчук О. В. Роль критичного мислення в сучасній освіті // Сучасні інформаційні технології та інноваційні методики навчання в підготовці фахівців: методологія, теорія, досвід, проблеми. 2018. Випуск 52. С. 2019-224. Режим доступу: http://nbuv.gov.ua/UJRN/mitimpt_52_53. 
9. Технологія розвитку критичного мислення INSERT. [Електронний ресурс] Режим доступу: http://vigivska0804.blogspot.com/2016/01/insert.html.

10. Гончаренко С. Український педагогічний словник. Київ, 1997. 376 с.

11. Bloom B.S. Taxonomy of educational objectives: The classification of educational goals: Handbook I, cognitive domain. New York: Longman, 1994. 112 p.

12. Пометун O.I., Сущенко I.M. Путівник 3 розвитку критичного мислення в учнів початкової школи. Київ: Освіта. 2017. 96 с.

13. Колток Л. Критичне мислення молодших школярів як психолого-педагогічний феномен // Молодь і ринок. 2019. № 9. С. 66-70. Режим доступу: http://nbuv.gov.ua/UJRN/Mir_2019_9_14.

14. Кроуфорд А., Саул В. Технології розвитку критичного мислення учнів. Київ: Вид-во «Плеяди», 2006. 220 с.

15. Метод кластер в освітньому процесі. Що це таке і як його використовувати? Портал вчителів початкових класів «Урок» - Portal of Primary school teachers. Режим доступу: http://www.yrok.net.ua/load/nova_ukrajinska_shkola/prijomi_roboti/metod_klastera_v_osvitnomu_pr ocesi_shho_ce_take_i_jak_jogo_vikoristovuvati/313-1-0-4593.

16. Шляйхер А. «Найкращий клас у світі: як створити систему освіти 21-го століття». Режим доступу: https://mon.gov.ua/storage/app/media/zagalna\%20serednya/yakist-osviti/shlyaykhernaykrashchiy-klas-u-sviti-yak-stvoriti-sistemu-osviti-21-go-stolittya.pdf.

\section{References:}

1. Postanova Kabinetu ministriv Pro zatverdzhennia Derzhavnoho standartu pochatkovoi osvity № 87 vid 21 liutoho 2018 roku. [About confirming State standard of primary education № 87 from February 21, 2018]. Retrieved from: https://zakon.rada.gov.ua/laws/show/87-2018-\%D0\%BF\#Text. [in Ukrainian].

2. Konverskyi A.Ie. (2020). Krytychne myslennia. Pidruchnyk dlia studentiv vyshchykh navchalnykh zakladiv usikh spetsialnostei. [Critical Thinking. Textbook for Students of Higher Educational Establishments of all Specialities]. Kyiv: Tsentr uchbovoi literatury [in Ukrainian].

3. Nova ukrainska shkola. Kontseptualni zasady reformuvannia serednoi shkoly [New Ukrainian school. Conceptual basis of reforming secondary school]. (2016). Retrieved from: https://mon.gov.ua/storage/app/media/zagalna\%20serednya/nova-ukrainska-shkola-compressed.pdf. [in Ukrainian].

4. Mykolaivskyi oblasnyi tsentr zainiatosti. Top navychok dlia uspikhu v 2025 rotsi [Mykolaiv regional employment center. Top skills for success in 2025]. Retrieved from: https://mik.dcz.gov.ua/publikaciya/topnavychok-dlya-uspihu-v-2025-roci. [in Ukrainian].

5. N. V. Vukina, N. P. Dementiievska, (2007). Krytychne myslennia: yak tsoho navchaty. [Critical thinking. How and what to teach]. Kharkiv: «Osnova»:«Tryada +» [in Ukrainian].

6. Tiahlo O. V. (2008). Krytychne myslennia. [Critical thinking]. Kharkiv: «Osnova»: «Tryada +» [in Ukrainian].

7. Terno S. O. (2012). Metodyka rozvytku krytychnoho myslennia shkoliariv u protsesi navchannia istorii. [Methodology of critical thinking development of students in teaching history]. Zaporizhzhia: Zaporizkyi natsionalnyi universytet [in Ukrainian].

8. Bielkina-Kovalchuk O. V. (2018). Rol krytychnoho myslennia v suchasnii osviti. [The role of critical thinking in contemporary education]. Suchasni informatsiini tekhnolohii ta innovatsiini metodyky navchannia $v$ pidhotovtsi fakhivtsiv: metodolohiia, teoriia, dosvid, problemy - Modern Information technologies and innovative teaching methodologies in Pedagogy of specialists: methodology, theory, experience, problems, 52, 2019-224. Retrieved from: http://nbuv.gov.ua/UJRN/mitimpt_52_53. [in Ukrainian].

9. Tekhnolohiia rozvytku krytychnoho myslennia INSERT. [Technology of critical thinking development INSERT] Retrieved from: http://vigivska0804.blogspot.com/2016/01/insert.html. [in Ukrainian].

10. Honcharenko S. (1997). Ukrainskyi pedahohichnyi slovnyk. [Ukrainian dictionary in Pedagogy]. Kyiv: Znannia [in Ukrainian].

11. Bloom B.S. (1994). Taxonomy of educational objectives: The classification of educational goals: Handbook I, cognitive domain. NewYork: Longman [in English].

12. Pometun O. I., Sushchenko I.M. (2017). Putivnyk z rozvytku krytychnoho myslennia $v$ uchniv 
pochatkovoi shkoly. [Guide in primary pupils critical thinking development]. Kyiv: Osvita [in Ukrainian].

13. Koltok L. (2019). Krytychne myslennia molodshykh shkoliariv yak psykholoho-pedahohichnyi fenomen. [Critical thinking of primary school pupils as psychological and pedagogical phenomenon]. Molod i rynok-Youth and market, 9, 66-70. Retrieved from: http://nbuv.gov.ua/UJRN/Mir_2019_9_14. [in Ukrainian].

14. Krouford A., Saul V. (2006). Tekhnolohii rozvytku krytychnoho myslennia uchniv. [Technologies of students critical thinking development]. Kyiv: Vyd-vo «Pleiady» [in Ukrainian].

15. Portal vchyteliv pochatkovykh klasiv «Urok». Metod klaster v osvitnomu protsesi. Shcho tse take i yak yoho vykorystovuvaty? [Cluster method in educational process. What is it and how to use it?]. Портал вчителів початкових класів «Урок» - Portal of Primary school teachers. Retrieved from:http://www.yrok.net.ua/load/nova_ukrajinska_shkola/prijomi_roboti/metod_klastera_v_osvitnomu_proce si_shho_ce_take_i_jak_jogo_vikoristovuvati/313-1-0-4593. [in Ukrainian].

16. Shliaikher A. Naikrashchyi klas u sviti: yak stvoryty systemu osvity 21 -ho stolittia. [The best class in the world: how to create the system of education in the 21-st century]. Retrieved from: https://mon.gov.ua/storage/app/media/zagalna\%20serednya/yakist-osviti/shlyaykher-naykrashchiy-klas-u-svitiyak-stvoriti-sistemu-osviti-21-go-stolittya.pdf. [in Ukrainian]. 